\title{
Dental caries profile in Monte Negro, Amazonian state of Rondônia, Brazil, in 2008
}

\author{
Roosevelt Silva BASTOS ${ }^{1}$, Ricardo Pianta Rodrigues SILVA ${ }^{1}$, Adelson Francisco MAIA-JUNIOR ${ }^{1}$, \\ Fábio Silva CARVALHO ${ }^{1}$, Sabrina MERLINI ${ }^{2}$, Magali Lourdes CALDANA ${ }^{3}$, José Roberto Pereira LAURIS ${ }^{4}$, \\ José Roberto Magalhães BASTOS 5
}

\begin{abstract}
1- DDS, MSc, PhD, Community Dentistry Graduate Student, Department of Pediatric Dentistry, Orthodontics and Community Health, Bauru School of Dentistry, University of São Paulo, Bauru, SP, Brazil.

2- DDS, Private Practice, Bauru, SP, Brazil.

3- DDS, PhD, Assistant Professor, Department of Speech-Language Patology/Audiology, Bauru School of Dentistry, University of São Paulo, Bauru, SP, Brazil.

4- PhD, Associate Professor, Department of Pediatric Dentistry, Orthodontics and Community Health, Bauru School of Dentistry, University of São Paulo, Bauru, SP, Brazil.

5- DDS, PhD, Professor, Department of Pediatric Dentistry, Orthodontics and Community Health, Bauru School of Dentistry, University of São Paulo, Bauru, SP, Brazil.
\end{abstract}

Corresponding address: Prof. Dr. José Roberto Magalhães Bastos - Faculdade de Odontologia de Bauru-USP - Departamento de Odontopediatria, Ortodontia e Saúde Coletiva - Al. Dr. Octávio Pinheiro Brisolla 9-75, Bauru-SP, Brasil, 17012-901 - Fone +55 $143235-8256$ Fax +55 14 $3223-4679$ - e-mail: zeromaba@fob.usp.br

Received: February 4, 2009 - Modification: September 05, 2009 - Accepted: September 28, 2009

\section{ABSTRACT}

\begin{abstract}
bjective: This epidemiological survey assessed the dental caries profile in Monte Negro, a small town in the Amazonian state of Rondônia, Brazil, and its relationship with the northern region, national and global goals for oral health in the years 2000 and 2020. Material and Methods: The groups randomly examined were composed of individuals aged $5,12,15$ to 19,35 to 44,65 to 74 years, living in both rural and urban areas. Results: The means dft (standard deviation) and DMFT (standard deviation) for the groups were, respectively, 3.15 (3.12), 3.41 (2.69), 5.96 (4.19), 16.00 (7.30) and 25.96 (9.82). Caries-free individuals were $34.42 \%, 14.81 \%$ and $8.16 \%$ in the preschoolchildren, schoolchildren and adolescent groups, respectively. The Significant Caries Index percentages applied to the two younger groups were 6.65 and 6.70 , and they increased to 32.00 in the individuals aged 65 to 74 years. Care Index percentages for adolescents, adults and elderly groups were, respectively, 29.40, 25.00 and 1.41 . The dental caries profile in Monte Negro in 2008 shows that, 8 years after the year 2000, no FDI/WHO goal for any age settled in 1982 has been achieved. Dental caries increased with age and the main dental problem of adult and elderly groups was tooth loss. Conclusion: Oral health promotion and prevention of oral disease policies are urgent needs. Setting of oral health goals and targets to people living in Monte Negro or Amazonia to be pursuit and achieved in a near future is an important action to do because of the culture, sanitary conditions and socioeconomic aspects of this particular population.
\end{abstract}

Key words: Dental caries. Dental health surveys. Public health dentistry. Cross-sectional studies.

\section{INTRODUCTION}

The interest on the assessment of the oral health profile was the reason of this epidemiological survey of the population living in Monte Negro, a small town in the Amazonian state of Rondônia, Brazil. The state of Rondônia is localized in the political northern region of Brazil and was emancipated on January $4^{\text {th }}, 1982$. Although its population has increased significantly in the last 10 years, even being far from the state capital
(Porto Velho), not much oral health information is available to the population, which reaffirms the need for epidemiological studies.

In 2003, a comprehensive national oral health survey was published regarding oral health conditions in Brazilian. All regions of the country - north, northeast, central west, southeast and south - were surveyed, including Porto Velho. Ariquemes, Pimenteiras do Oeste and Xupinguaia were publically and randomly sorted and these populations were examined ${ }^{8}$. Data were published 
in a report by the Oral Health National Coordination of the Brazilian Health Ministry by region; obviously data collected from these towns were part of the northern region data?.

Monte Negro means "Black Mount", and this name reminds a topographic accident of the region. The emancipation of this town has occurred by the Federal Law N. 378, signed by the Governor of Rondônia on February $13^{\text {th }}, 1992$. The current population of Monte Negro is 12,357 inhabitants and it is located at longitude $63^{\circ} 19^{\prime} 31^{\prime \prime}$ west and latitude $10^{\circ} 17^{\prime} 40^{\prime \prime}$ south, far 181.82 kilometers from Porto Velho, occupying an area of 1,931.37 square kilometers into the Amazonian biome. The Gross Domestic Product (GPD) distribution is 55\% for services, $37 \%$ for agriculture and cattle feeding and only $9 \%$ to industry. All 7 health institutions are supported by public resources ${ }^{13}$.

Over the last 30 years, a significant decline of dental caries has occurred first in developed countries and then in developing countries as well too, in the young groups $s^{1,2,10,15,16,1618,19,20,23,25,26,27}$. In Brazil, the fluoridation of public water supply is determined by federal law since $1974^{4}$, but since then not all the municipalities has implemented this prevention method. In Monte Negro, for example, there is not such a policy. In 1989, a federal legislation was approved and since then Brazilian dentifrices are fluoridated in a known and scientific approved condition to the market ${ }^{5}$.

This epidemiological survey assessed the dental caries profile in Monte Negro, and its relationship with the Northern region, national and global goals for oral health in the years $2000^{9}$ and $2020^{11}$.

\section{MATERIAL AND METHODS}

\section{Ethical aspects}

This epidemiologic study was approved by the Institutional Review Board (IRB) of Bauru School of Dentistry, University of São Paulo, Brazil, in accordance to the Brazilian Resolution 196/96, which regulates research on human beings (process $\left.n^{\circ} 25 / 2008\right)$.

Table 1- Sample distribution according to age and gender
Sample

In order to obtain a sample size with a confidence level of $95 \%$ and design error of $2 \%$, data calculated in 2003 for towns with 5,000 to 10,000 inhabitants for the Brazilian northern region to the national oral health conditions survey were adopted as an objective ${ }^{8}$. The sample sizes calculated for those towns were 83, 94, 83, 48 and 14 for groups aged to 5, 12, 15-19, 35-44 and 65-74-year-old, respectively. All participants were chosen at random and signed their agreements.

The 5-year-old participants were all from the same kindergarten in an urban area and totalized two thirds of all of schoolchildren. All the children of this age who were at school on that day of study were examined. In the rural area, there were no institutions attending preschoolchildren, and hence it was impossible to assess this age group. The same occurred to the group of elderly people (65-74 years old) and no data were collected from rural area. The urban area data collection was possible by the cooperation of the Independent League of Rural Health (LISURA) bringing to the place of exams this age group. The group of 12 was assessed by school in both areas. The index age of 15 was grouped to the ages of 16 to 19 because the sample would be the same used by Brazilian national surveys since $1986^{6}$. The group of adults (35-44 years old) was composed of teachers and employees from the schools at which the examiners worked during the survey.

\section{Examination methodology}

Two different examiners worked in this survey. Firstly, theoretical discussions about diagnostic criteria of dental caries were performed for calibration before collecting data ${ }^{26}$. In a second moment, 6 subjects from the group of adolescents were examined by each dentist. In a third moment, the calibration process ran with 12 subjects of the same age group. At this last moment the kappa statistics was 0.84 .

All exams were undertaken with the participants sitting on chairs, under natural light, with the examiners standing in front of them and using dental mirror and CPI probe (Community

\begin{tabular}{ccccccc}
\hline Age & \multicolumn{2}{c}{ Female } & \multicolumn{2}{c}{ Male } & \multicolumn{2}{c}{ Total } \\
\hline & $\mathbf{n}$ & $\%$ & $\mathbf{n}$ & $\mathbf{0}$ & $\mathbf{n}$ \\
\hline 5 & 31 & 50.82 & 30 & 49.18 & 61 \\
12 & 45 & 55.56 & 36 & 44.44 & 81 \\
\hline $15-19$ & 41 & 41.84 & 57 & 58.16 & 98 \\
\hline $35-44$ & 43 & 58.90 & 30 & 41.10 & 73 \\
\hline $65-74$ & 29 & 51.79 & 27 & 48.21 & 56 \\
\hline Total & 189 & 51.22 & 180 & 48.78 & 369 \\
\hline
\end{tabular}


Periodontal Index probe) ${ }^{28}$.

\section{Data analysis}

For the presentation of DMFT index ${ }^{14}$, statistical description was performed to determine the percentage of caries-free individuals and the mean participation of each part of this index (decayed, missing and filled permanent teeth) for all ages studied. To determine the Significant Caries Index (SiC Index) ${ }^{3}$, the DMFT index was grouped individually by score, and the mean was calculated on the one third highest cases.

\section{RESULTS}

The sample distribution can be seen in Table 1 , according to gender, age groups and male-tofemale ratio. Table 2 shows the mean dft (SD) for the 5-year-olds and the mean DMFT (SD) for the other age ranges as well as their components (SD) and the percentage of caries-free individuals. The SiC Index was calculated as recommended by Brathall $^{3}$ (2000). The Care Index ${ }^{24}$ was calculated without the caries-free data, the filled teeth mean

Table 2- Dental caries [dft(SD) and DMFT(SD)] distribution by component [decayed - DT(SD), missing - MT(SD), filled FT(SD)], Caries-free (\%), SiC Index and Care Index in each age studied

\begin{tabular}{|c|c|c|c|c|c|c|c|c|}
\hline Parameters & $\begin{array}{l}\text { dft } \\
\text { (SD) }\end{array}$ & $\begin{array}{l}\text { DMFT } \\
\text { (SD) }\end{array}$ & $\begin{array}{c}\text { DT } \\
\text { (SD) }\end{array}$ & $\begin{array}{l}\text { MT } \\
\text { (SD) }\end{array}$ & $\begin{array}{c}\text { FT } \\
\text { (SD) }\end{array}$ & $\begin{array}{c}\text { Caries-free } \\
(\%)\end{array}$ & SiC Index* & $\begin{array}{c}\text { Care Index } \\
(\%)^{* *}\end{array}$ \\
\hline \multicolumn{9}{|l|}{ Age } \\
\hline 5 & $\begin{array}{l}3.15 \\
(3.12)\end{array}$ & - & $\begin{array}{c}2.67 \\
(3.06)\end{array}$ & $\begin{array}{c}0.00 \\
(0.00)\end{array}$ & $\begin{array}{c}0.48 \\
(1.15)\end{array}$ & 34.42 & 6.65 & 23.30 \\
\hline 12 & - & $\begin{array}{c}3.41 \\
(2.69)\end{array}$ & $\begin{array}{c}2.53 \\
(2.24)\end{array}$ & $\begin{array}{c}0.25 \\
(0.64)\end{array}$ & $\begin{array}{c}0.63 \\
(1.45)\end{array}$ & 14.81 & 6.70 & 21.72 \\
\hline $15-19$ & - & $\begin{array}{c}5.96 \\
(4.19)\end{array}$ & $\begin{array}{c}3.27 \\
(2.87)\end{array}$ & $\begin{array}{c}1.09 \\
(1.59)\end{array}$ & $\begin{array}{c}1.62 \\
(2.66)\end{array}$ & 8.16 & 10.61 & 29.40 \\
\hline $35-44$ & - & $\begin{array}{l}16.00 \\
(7.30)\end{array}$ & $\begin{array}{c}2.21 \\
(2.33)\end{array}$ & $\begin{array}{c}9.79 \\
(8.65)\end{array}$ & $\begin{array}{c}4.00 \\
(4.16)\end{array}$ & 0.00 & 24.38 & 25.00 \\
\hline $65-74$ & - & $\begin{array}{l}25.96 \\
(9.82)\end{array}$ & $\begin{array}{c}0.89 \\
(1.60)\end{array}$ & $\begin{array}{c}24.71 \\
(10.74)\end{array}$ & $\begin{array}{c}0.36 \\
(1.15)\end{array}$ & 1.78 & 32.00 & 1.41 \\
\hline
\end{tabular}

${ }^{*} \mathrm{SiC}$ Index = means one third \% higher DMFT

${ }^{* *}$ Care index $=($ FT/DMFT $) \times 100$, DMFT $>0$

Table 3- Global goals for oral health in the years 2000 and 2020 related to the results of oral health survey in Monte Negro, Rondônia (2008) and Brazil (2003)

\begin{tabular}{|c|c|c|c|c|c|}
\hline Age (years) & 5 & 12 & $15-19$ & $35-44$ & $65-74$ \\
\hline Parameters & Caries-free \% & $\begin{array}{l}\text { DMFT at } 12 \text { years- } \\
\text { old }\end{array}$ & Complete denture $\%$ & $\begin{array}{c}\text { Minimum of } 20 \\
\text { functional teeth } \\
\%\end{array}$ & $\begin{array}{c}\text { Minimum of } 20 \\
\text { functional teeth } \\
\%\end{array}$ \\
\hline $2000^{*}$ & 50.00 & No more than 3.00 & 85.00 minimum & 75.00 minimum & 50.00 minimum \\
\hline $\begin{array}{c}\text { Monte Negro } \\
2008\end{array}$ & 34.42 & 3.41 & 54.08 & 67.12 & 16.07 \\
\hline $\begin{array}{l}\text { SBBrasil } \\
2003 N^{* *}\end{array}$ & 35.04 & 3.13 & 39.13\# & 46.34 & 8.58 \\
\hline $\begin{array}{l}\text { SBBrasil } \\
2003^{* * *}\end{array}$ & 40.62 & 2.78 & 55.09\# & 53.96 & 10.23 \\
\hline $2020^{* * * *}$ & $\begin{array}{l}\text { To increase } \\
\text { proportion by } \\
\text { X\% }\end{array}$ & $\begin{array}{c}\text { To reduce X\% } \\
\text { particularly the DT } \\
\text { component }\end{array}$ & 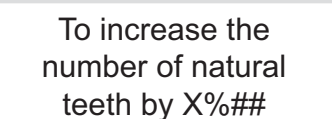 & $\begin{array}{c}\text { To increase its } \\
X \%\end{array}$ & $\begin{array}{c}\text { To increase its } \\
\mathrm{X} \%\end{array}$ \\
\hline
\end{tabular}

${ }^{*}$ FDI/WHO (1982). Global goals for the year 2000

${ }^{* *}$ SBBrasil 2003, Northern region

***SBBrasil 2003

****WHO/FDI/IADR (2003). Global goals for the year 2020

\#Data corresponds to individuals with 18 years of age

\#\#This goal was published for persons of 18 years old 
(FT) was divided by the DMFT means and multiplied by 100 .

The data collected in Monte Negro has been confronted to the data found on Brazilian Oral Health Survey (SB Brazil Project) ${ }^{7}$ (2000), by national means and Brazilian northern region data. The global goals for the years $2000^{9}$ and $2020^{11}$ are showed in Table 3. The percentage of cariesfree individuals at 5 years of age was similar to that of the northern region and did not achieve the Fédération Dentaire Internationale/World Health Organization (FDI/WHO) goal for the year 2000. The mean DMFT at the age of 12 was higher than the regional, national and to the FDI/WHO goal for the year $2000^{\circ}$. The teenagers, adults and the elderly group were represented by randomly chosen individuals with age between 15 and 19, 35 and 44 and 65 and 74 years old. In any of these cases the goal for oral health by the year 2000 was achieved in Monte Negro in 2008, as for Brazil and Northern region in 2003.

\section{DISCUSSION}

The most difficult situation on assessing health data from any part of Amazonia is to get there. The University of São Paulo (USP) has been working in the small town of Monte Negro for several years promoting health. Physicians, biologists, nurses, students and graded health professionals have been working there under coordination of Professor Marcelo Aranha Camargo. In 2002, Bauru School of Dentistry from USP was invited to take part of the program involving the population in both urban and rural areas. The participation of Bauru School of Dentistry was first coordinated by Professor José Roberto de Magalhães Bastos from the Department of Pediatric Dentistry, Orthodontics and Collective Health, and since 2006 it has been coordinated by Professor Magali de Lourdes Caldana, from the Department of Speech and Hearing Pathology, Bauru School of Dentistry.

USP's undergraduate and graduate dental students, professors, chairmen and other employees have gathered efforts to travel with the will of providing health for al/27. At Bauru School of Dentistry, this program has been kindly named as "USP in Rondônia".

The primary main problem was to assess the real epidemiological conditions of health. This report shows dental caries data from an oral health survey undertaken by a team of professional from Bauru School of Dentistry in Monte Negro in 2008 using WHO criteria ${ }^{28}$.

From the total of inhabitants living in Monte Negro, $54.68 \%$ live in the rural area $^{13}$, which means a spread population to be reached. The low percentage of elderly people was another difficult with regard of the group of 65 to 74 years old.

The percentage of caries-free preschool children in 2008 did not achieve the global goal for the year
2000, but the same analysis can be done to the northern region and to Brazil in 2003. No dental prevention program had been implemented by the municipality in the only public kindergarten in the town. Even though, no missing teeth were found in the deciduous dentition and there were $34.42 \%$ of caries-free preschoolchildren at the age of 5. Probably the use of fluoridated dentifrices or other fluoride sources might be the reason of such results ${ }^{21}$.

Among the 12-year-old schoolchildren, only $14.81 \%$ of the permanent teeth were not cavited, and the mean DMFT was 3.41 (2.69), almost borderline to the FDI/WHO goal of no more than 3.00 reached 8 years before. The dramatic concern is upon the Care Index of $21.72 \%$, related to the low participation of "filled teeth" in the composition of DMFT (Table 2). The prevalence of decayed teeth $[2.53(2.24)]$ is what makes the Care Index so much low. In another area of Amazonia, in Ecuador, dental caries survey ran with WHO criteria and the dental caries conditions showed necessities in the assistance and prevention aspects for 12 -year-old schoolchildren ${ }^{17}$, in the same way as in Monte Negro. The SiC Index is another way to understand the severe problem of dental caries in Monte Negro. At 12 years of age, the mean of the one third higher DMFT is almost twofold higher than the general mean, which indicates the great inequalities occurring in oral health between these schoolchildren. A low prevention measure along with low treatment has been occurring despite of the disease incidence. Even though, the dental caries polarization phenomenon can be observed in this study, regarding, probably, the consequence of the use of fluoridated dentifrices.

The incidence of dental caries normally increases with age, which has been confirmed in this epidemiologic survey. The DMFT increased to 5.96 (4.19) in the group of adolescents. The "decayed teeth" component contributed with half of this index [3.27(2.87)]. In the 15 to 19 age range, the Care Index still shows a low percentage (29.40), which is a concern as to the urgent need of a better access to dental assistant. The missing teeth component starts to be an important concern. Not only because of higher DMFT or the objectives of FDI/WHO ${ }^{9}$ (2000) were not been achieved itself. The most important reason is the inequalities those people will pass over life if a preventive measure urgently not appears as soon as possible to the next generations. The decline of dental caries in young ages may influence dental caries profile of adolescents and the epidemiologic surveys are necessary to follow up ${ }^{12}$.

Adults are suffering more with tooth loss then other age groups. No one single case was cariesfree and the SiC Index was 24.38. Low dental caries prevention measures during childhood and adolescence leads an adult life suffering the consequences of dental decay of the younger 
years. Decayed teeth are not the main contribution to DMFT anymore, but it is rather the smallest one $[2.21(2.33)]$. The "missing teeth" component represented by the score $9.79(8.65)$ and the SiC Index 24.38 lead to conclude the urgent need for oral rehabilitation. Obviously, periodontal disease is not described here, and it is certainly another reason of concern by public health policies.

In the elderly group, represented by people aged 65 to 74 years, despite the percentage of $1.78 \%$ for caries-free, which corresponds to one male participant, the most prevalent problem was related to tooth loss. The component "missing teeth" was 24.71 (10.74) and the general mean DMFT of this group was 25.96 (9.82). As expected, the maximum SiC Index was 32.00. These data show the strongly neglected oral health-related quality of life; almost the entire sample needed to use artificial dentures. The Care Index (1.41\%) also confirms the low primary attention. As the findings of Rihs, et al. ${ }^{20}$ (2009) in the state of São Paulo, Brazil, elderly people living in Monte Negro also need specific programs to be established and public health policies to enhance their access to dental assistance ${ }^{22}$.

\section{CONCLUSIONS}

Dental caries profile in Monte Negro in 2008 shows that, 8 years after the year 2000, no goal for any age settled by FDI/WHO in 1982 has been achieved. Oral health in Monte Negro can be synthesized in a word: "necessities". Oral health promotion and policies for prevention of oral disease are urgent needs. Setting of oral health goals and targets to people living in Monte Negro, Rondônia, Northern region of Brazil or to the Amazonian people, and even for Brazil, as a country, to be pursuit and achieved in a near future is an important action to do because of the culture, the sanitary conditions and socioeconomic aspects of this particular population.

\section{REFERENCES}

1- Bastos RS, Bijella VT, Buzalaf MAR, Bastos JRM. Dental caries decline and increment on percentage of caries free schoolchildren, 12 years old, in Bauru, São Paulo, between 1976 and 1995. Rev Fac Odontol Bauru. 2002;10:75-80.

2- Bastos RS, Olympio KP, Bijella VT, Buzalaf MA, Bastos JRM. Trends in dental caries prevalence in 12-year-old schoolchildren between 1976 and 2001 in Bauru, Brazil. Public Health. 2005;119(4):269-75.

3- Brathall D. Introducing the Significant Caries Index together with a proposal for a new global oral health goal for 12-year-olds. Int Dent J. 2000;50(6):378-84.

4- Brasil. Lei Ordinária no 6050 de 24 de maio de 1974. Dispõe sobre a fluoretação da água em sistemas de abastecimento quando existir estação de tratamento. Diário Oficial [da] República Federativa do Brasil, Poder Executivo, Brasília (1974 May 27). 5- Brasil. Ministério da Saúde. Portaria no 22/SNVS de 20 de dezembro de 1989: Define normas para registro e controle de enxaguatórios bucais com flúor para uso diário e de dentifrícios com flúor. Diário Oficial da União, Brasília (1989 Dec. 22); Sec. 1:24-171.
6- Brasil. Ministério da Saúde. Secretaria Nacional de Programas Especiais de Saúde. Divisäo Nacional de Saúde Bucal. Fundação Serviços de Saúde Pública. Levantamento epidemiológico em saúde bucal: Brasil, zona urbana. 1986. Brasília: Centro de Documentaçäo do Ministério da Saúde; 1988.

7- Brasil. Ministério da Saúde. Secretaria de Atenção à Saúde. Departamento de Atenção Básica. Coordenação Nacional de Saúde Bucal. Projeto SB Brasil 2003: condições de saúde bucal da população brasileira 2002-2003: resultados principais. Brasília: Ministério da Saúde; abr. 2004.

8- Brasil. Ministério da Saúde. Secretaria de Políticas da Saúde. Departamento de Atenção Básica. Área Técnica de Saúde Bucal. Projeto SB 2000: condições de saúde bucal da população brasileira no ano 2000. Manual do Examinador. Brasília: 2001.

9- Fédération Dentaire Internationale. Global goals for oral health by the year 2000. Int Dent J. 1982;32(1):74-7.

10- Glass RL. Introduction - the first international conference on the declining prevalence of dental caries. J Dent Res. 1982;61(Sp. Iss): $1301-83$.

11- Hobdell M, Petersen, PE, Clarkson J, Jhonson N. Global goals for oral health 2020. Int Dent J. 2003;53(5):285-8.

12- Hugo FN, Vale GC, Ccahuana-Vásquez RA, Cypriano S, Sousa Mda L. Polarization of dental caries among individuals aged 15 to 18 years. J Appl Oral Sci. 2007;15(4):253-8.

13- IBGE. Estatística do Registro Civil de 2006; Malha municipal digital do Brasil: situação em 2006. Rio de Janeiro: IBGE; 2007.

14- Klein $\mathrm{H}$, Palmer CE. Dental caries in American Indian children. Public Health Bull. Washington: GPO; 1937. p. 239.

15- Marthaler TM. Caries status in Europe and predictions of future trends. Caries Res. 1990;24:381-96.

16- Marthaler TM. Changes in dental caries 1953-2003. Caries Res. $2004 ; 38(3): 173-81$.

17- Medina W, Hurtig AK, San Sebastián M, Quizhpe E, Romero, C. Dental caries in 6-12-year-old indigenous and non-indigenous schoolchildren in the Amazon basin of Ecuador. Braz Dent J. 2008;19(1):83-6.

18- Murray JJ. Comments on results reported at the Second International Conference "Changes in caries prevalence". Int Dent J. 1994;44(4 Suppl 1):457-8.

19- Narvai PC, Frazão P, Roncalli AG, Antunes JL. Dental caries in Brazil: decline, polarization, inequality and social exclusion. Rev Panam Salud Publica. 2006;19(6):385-93.

20- Pitts NB, Evans DJ, Nugent ZJ, Pine CM. The dental caries experience of 12-year-old children in England and Wales. Surveys coordinated by the British Association for the Study of Community Dentistry in 2000/2001. Community Dent Health. 2002;19:4653.

21- Ramires I, Pessan JP, Levy FM, Rodrigues MH, Almeida BS, Kato MT, et al. Prevalence of dental fluorosis in Bauru, São Paulo, Brazil. J Appl Oral Sci. 2007;15(2):140-3.

22- Rihs LB, Silva DD, Sousa Mda L. Dental caries in an elderly population in Brazil. J Appl Oral Sci. 2009;17(1):8-12.

23- Sales-Peres SH, Bastos JR. An epidemiological profile of dental caries in 12-year-old children residing in cities with and without fluoridated water supply in the central western area of the State of São Paulo, Brazil. Cad Saude Publica. 2002;18(5):1281-8.

24- Smith GE. Tooth decay in the developing world. N Z Med J. 1987;100(834):669-70.

25- Tagliaferro EP, Meneghim MC, Ambrosano GM, Pereira AC, Sales-Peres $\mathrm{SH}$, Sales-Peres A, et al. Distribution and prevalence of dental caries in Bauru, Brazil, 1976-2006. Int Dent J. 2008;58(2):75-80.

26- World Health Organization. Calibration of Examiners for Oral Health Epidemiology Surveys. Technical Report. Geneva: WHO; 1993.

27- World Health Organization. International Conference on Primary Health Care. Alma-Ata 1978: primary health care; report of the International Conference on Primary Health Care, Declaration of Alma-Ata. Geneva: World Health Organization; 1978.

28- World Health Organization. Oral health surveys: basic methods. 4th ed. Geneva: ORH; EPID; 1997. 